\title{
Evaluation of the conservation activities in the historical settlement Tenedos-Bozcaada Island
}

\author{
F. Akpınar, N. Saygin \& E. Karakaya \\ City and Regional Planning Faculty of Architecture, \\ Izmir Institute of Technology, Turkey
}

\begin{abstract}
The efforts for the conservation of cultural heritage in historical settlements are a highly problematic and multi-faceted issue in Turkey. Although the conservation legislation dates back 50 years, the cultural heritage has not been internalized and not accepted in wider parts of the society and, has not found a solid political base. The historical and cultural heritage areas are mostly marketed for tourism and turned into places as the simulacrum of the elitist and middle class tastes. Tenedos (Bozcaada) Island inherits the rich cultural heritage of two millennia.The Island is in danger of losing its social, cultural and multi-ethnical characteristic where Turkish and Greek societies live harmoniously. The architectural, economic and ecological values are also in danger because of the rise of touristic activities and the construction of vacation homes as well as the State's withdrawal to provide subsidy to the agricultural sector that took place after the 1980s in parallel with the general economic policies adopting global economic restructuring. The objective of the paper is to highlight the multidimensional character of the social and spatial process which is enmeshed in the conservation activities of the Island. The values and norms, social, economic considerations in the conservation activities need a new approach and, without existence of a common will and a wider participation of the society it is hard to expect any success in the conservation of the rich cultural values, and to assess, develop and carry them into the future.

A bundle of techniques are used: a large survey analysis of the area is realized and its social, historical and physical characteristics are documented. Questionnaires, in-depth interviews are used in order to detect the difficulties for conservation of the heritage in part of the responsible public bodies. The public and tourism sector opinions, thoughts and aspirations are surveyed. Even though,
\end{abstract}


the preservation of Tenedos Island's cultural heritage appears to be a difficult challenge, there seems to be some positive clues for the future.

Keywords: cultural heritage, conservation planning, spatial strategic planning, identity, participation and sustainability.

\section{Introduction}

Turkey has been going through a rapid transformation of urbanization, metropolitanization, coastalisation period while facing the challenges of globalization and integration into the global markets. This multi-dimensional makeup has complicated the protection of natural and historical resources and lead to some irreversible destruction of the cultural assets and heritage. The changes in the public lifestyle, the fancy for different taste and the changes in vacation concept, have vastly transformed the coastal areas with rich history and cultural wealth, into resort towns, attracting tourism sector investors and many vacationers while losing their authentic nature and structure. We, as the planners, would like to concentrate on managing and regulating this transformation in an active fashion, instead of opposing it.

In this study, main intention is to reveal the economic, social, legal, administrative and spatial implications of Bozcaada's multi-dimensional and complicated conservation challenge, and to demonstrate a strategic framework for managing the Island's transformation. A mixed research approach of quantitative and qualitative study is held on bringing together the Island's changing- recessive agricultural and manufacturing sector, the newly developing service sector (tourism), the administrative branches that regulate and manage the transformation and the public sector and conservation groups. The purpose of the study is to present the conservation profile of Bozcaada, discuss the Island's local context in relation with the country's urban conservation context. The definition of the challenge dictates identification of the attributes of the solution. The following four areas come forward: (1) Identity and evaluation of the inhabitants (2) Social cohesion (3) Legal-administrative shortcomings and offerings, (4) Economic sustainability.

\section{Brief curricula of Tenedos-Bozcaada Island}

Tenedos-Bozcaada Island is located on the Northwestern Aegean coast, 12 nautical miles from the Dardanelle (Çanakkale) Straits (Hellespont), just west of the coastline of ancient city of Troy (Map 1). The Island is a town (ilçe) by itself and also has an elected local administration (municipality). Tenedos is one of the two islands in the Northern Agean Sea, the other one, Imbros which is 17 nautical miles away. The Island is of part of Çanakkale Province in Turkey. Though Tenedos is a small island encompassing an area of $37.6 \mathrm{sq} . \mathrm{km}$., it is the third biggest island of the nation after Imbros (Gökçeada) and Marmara, in the Marmara Sea. The Island is four nautical miles away from the main land, and in Geyikli Port, the ferryboats travel between the Island and the mainland. The largest settlement area is located in the northeastern part of the Island. 


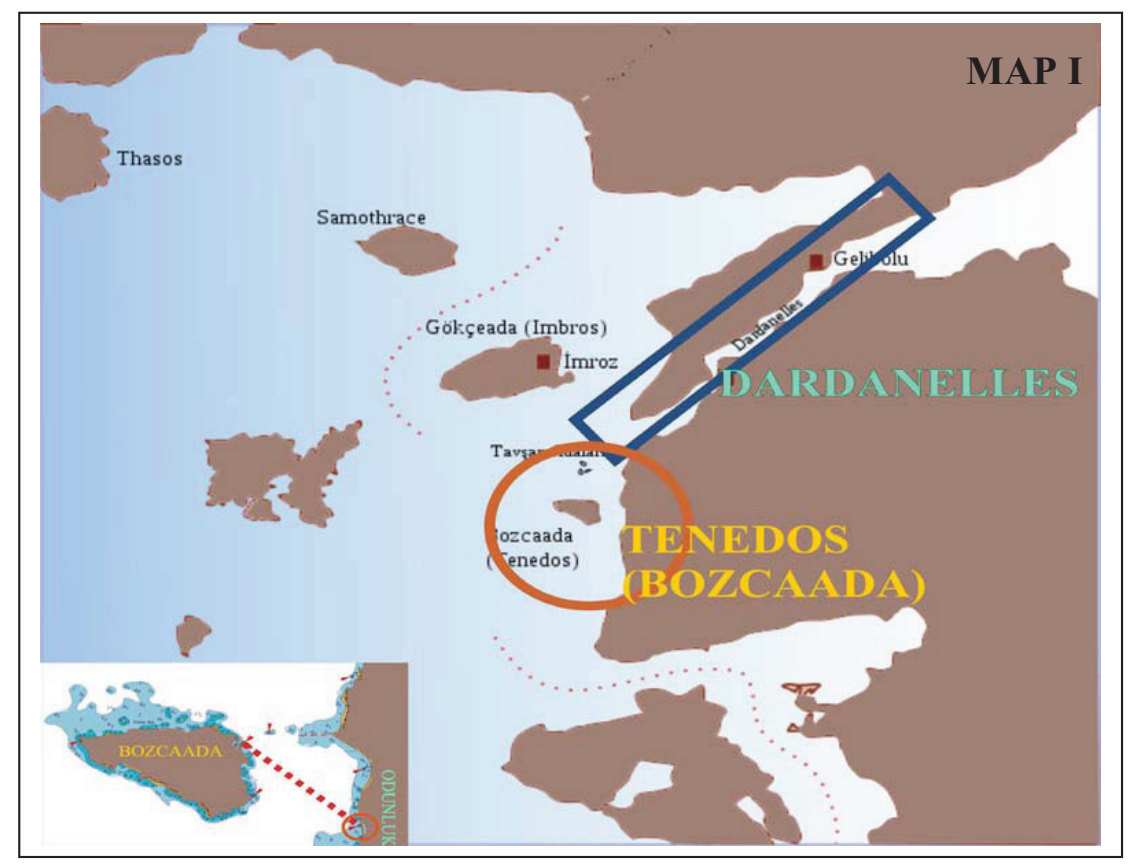

Map 1.

In Turkish, Bozcaada translates to 'Barren Island', due to the fact that the Island has been characterized largely as dry land with limited resources for exploitation. In the past, the economy of the Island has been mainly fishing and maritime commerce [1]. Until the end of the Classical Antiquity, the Island acted as a base port or shelter for the ships of modest sizes before they made their way into the Sea of Marmara. This strategically important small island was also exploited for agrarian purposes and viniculture has been one of the most important features of the Island's rural economy for centuries. Bozcaada's population according to the last census records is 2354 people (year 2010), however in summer time, it exceeds 8000 people.

\section{Brief history of the Tenedos-Bozcaada}

In Homer's Iliad and the Odysseia, there are references to the Island's importance [2], where the Island's inlets and bays provided protection for the Hellenistic Army during the Trojan War. In his saga, Aeneid (II. 30, II. 135), written in 1 B.C., the Roman writer, Vergilius talks about events after the collapse of Troy and writes about Aeneas surviving the Trojan war and his arrival to Italy and his adventure of founding Rome:

"There is an island across from the mainland. It is the island of legendary Tenedos. During the kingdom of Priamos, the islanders lived in wealth 
and comfort but now, it is empty and the harbour is not efficient even to drop an anchor. The Greeks came and hid here." [2]. (translation belongs the authors).

During the period, after 133 B.C. with the increasing influence of Roman Empire in Anatolia, Tenedos went through political development. The construction of an artificial harbour at Alexandreia Troas, which took over as the control of the world trade route, at the mouth of the Dardanelle Strait might have been a negative factor that subsequently resulted in the decline of the social and economic life in Tenedos in the Roman Era and Late Antiquity [1]. At the end of Classical Antiquity, mainly in 6 B.C., Tenedos harbour regained its importance, especially after the port on the mainland lost its effectivity due to geomorphological changes. Due to its strategic location to the Dardanelles Strait, the Tenedos Harbour played an active role for the East Roman Empire trade.

Tenedos was very important for the Ottomans due to the strategic location on the mouth of the Dardanelle Strait. The climactic moment came in 1453, when the last Byzantine emperor, Constantine XI, perished in battle, leaving the sultan Mehmet II, the Conqueror (Fatih), as the master of a multinational empire and İstanbul was in the hand of Ottomans. The Island was conquered by the Sultan Mehmet II, in 1455 after the conquest of the Istanbul. The very first major accomplishment of Fatih Sultan Mehmet was to rebuild the Island's fort. And many Ottoman structures such as mosques, medressehs, fountains and hamams were built by the Ottoman sultans. In the Ottoman times, Bozcaada was governed by a castellan and a kadi, and at the end of the nineteenth century, a governorship was constituted in the Island, adhered to the Starboard of the Lesbos Island which was a part of the 'Island of Mediterranean' (a Province named as Cezair-i Bahr-i Sefid) State of the Otoman Empire [3].

During the Balkan Wars, the Island was invaded by the Greek Navy and came under the Greek control. When the Turkish War of Independence ended with the Greeks' defeat in Anatolia, the Western World agreed to the new Turkish Republic, in 1923 by the Treaty of Lausanne which made Bozcaada and Gökçeada part of Turkish Republic, and exempt them from the population exchange that took place between Greece and Turkey. The Greek inhabitants of the two islands were allowed to stay and keep their school and churches. Over the years, many Greek families have left and only few families at present live in the Island (approximately 20 people).

\section{Physical structure of Bozcaada}

The built up area of Bozcaada, which is the urban conservation site is located on the northeastern part of the Island, at the skirts of the castle, where the slopes surrounding the settlement reaches the sea in a valley form (Map 2). The main axis, Çınarçarşı Caddesi divides the settlement into two, where the Alaybey Neighborhood is located on the south, whereas Cumhuriyet Neighborhod is located to the north. Historically the Turkish citizens has resided at the Alaybey Neigborhood, known as Turkish District and the Greek citizens reside at the Cumhuriyet Neigborhood, known as Greek District in the daily speech. The 
traditional fabric from the $19^{\text {th }}$ century of Bozcaada presents typical architectural features of Western Anatolia. The religous structures are scattered around the two neighborhoods; the Alaybey Mosque (registered as monument), in it's courtyard there is a historic cemetery from the Ottoman Era, Köprülü Mehmet Pahsa Mosque (registered as monument), the Namazgah Fountain, hamams etc., are found in Alaybey (Turkish) district, and the others, a Church Virgin Mary (the belfry of the church, which is of $23.8 \mathrm{~m}$ height, was restored in 2006), a chapel is located in Cumhuriyet (Greek district).

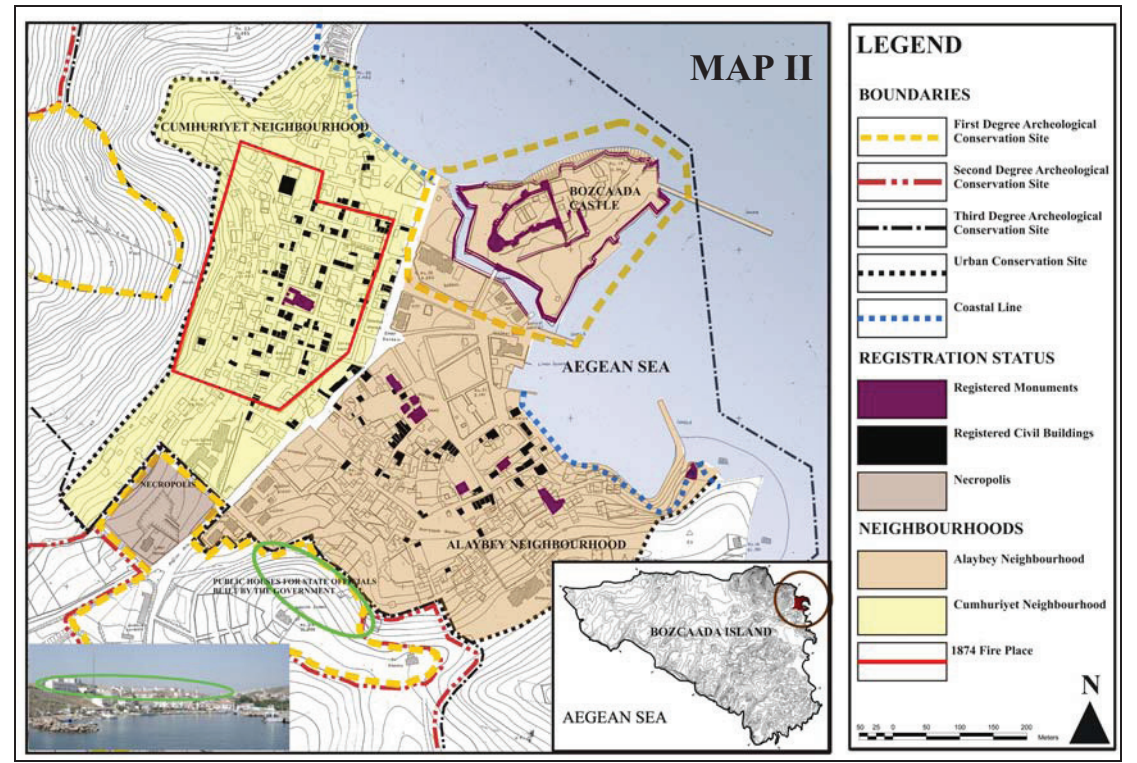

Map 2.

There was a destructive fire in the Cumhuriyet district which burned up nearly the entire neighborhood in 1874. The neighborhood was reconstructed with a grid-iron plan following the fire [4]. The streetscapes in the Turkish side are composed of very organic and intrinsic quality. The traditional buildings are made of masonry and timber frame structures. There are slight differences in architectural styles between the Turkish and Greek neighborhoods. The Greek Houses have basements where the kitchen, bathroom and laundry are located. The windows are high and wide with shutters. Upper floors are made of timber, with high windows and balconies, different from the Turkish houses. Many houses have extensions with high walls called anexes (măgaza) used for vine production and storage for winter supplies [5]. In the Turkish Neighborhood, the basement is of higher floors with narrow window openings, which are used for storage and gizzard. In the houses there are closets, a small bathing area, gusülhane (a small niche suitable for bathing in the traditional housing), and timber ceilings. In the countryside the vineyard houses are located to meet the 
needs of the agricultural production. The rooms are composed of kitchen and barn. The two story houses are called 'tower (kule), and one story is called dam type. Except for the renovated buildings apt to it's original function, some of the vineyard houses are used for vacation homes.

\section{Conservation planning efforts}

In Turkey, the first enactments for preservation appeared in the $19^{\text {th }}$ century with regulations concerning old monuments. In the modern times, the $1973 \mathrm{Law}$ on Old Monuments was preceded by the 1983, Law on the Conservation of Cultural and Natural Beings (Law of no. 2863). The law provoked the development of a substantial legislation further supported by National Parks and Environment, and international charters further enlarged the content of conservation [6]. The first planning efforts of Bozcaada were done by the Urban Planning Department of Bank of Provinces (Iller Bankasi) and approved by the Supreme Council of Immobile Historical Assests [4]. With this plan, the entire island was designated as "natural conservation site", traditional urban fabric was preserved and a limited area was designated for new development. The second Conservation Plan of Bozcaada was developed again by the Urban Planning Department of Iller Bankası in 1994. A new effort for conservation plan has been started as the result of the decision to end this plan and a new conservation plan needs to be developed by the Çanakkale Regional Conservation Council. The financial resource for the planning efforts is provided by the 'Contribution Fund for Conservation of the Immobile Cultural Assets of the Immobile Cultural Assets', (law 2863, article 12) from the $\dot{I l}$ Özel Idaresi (Province's Special Administration) and Bozcaada Municipality provided a start to process of the Conservation Plan development. The new planning is expected to come into effect soon. The public authority have made the decision that the Island was under conservation and by doing this, the island was prevented from the massive construction of vacation homes flourished in the coastline of the Nation. However, there is controversy that, although the the necropol area and its surroundings, are designated 'First degree Archeological Site', as one can see easily in the Map 2, that the public houses have been built for the state officials within the immediate surroundings of necropol area. The size and architectural features of the buildings do not fit the traditional fabric; in addition they have a damaging effect of the unique silhoutte of the Island. In the dwelling area of the Island, there are nine registered monumental structures (including historical mosques, church, fountains, cemeteries and Bozcaada Castle), and 134 registered civil architectural buildings can be found.

\section{Tenedos-Bozcaada: identity and visioning of the settlement}

In the academic circle, the rapid urbanization and construction that have taken place in the country very rapidly and most of the time illegally, creating very similar, uniform settlements, cities without an identity, is one of the mainly discussed and agreed topics. It is hard to say that the protection of the rich 
historical culture and making it available for the future generations is well executed. Cultural heritage in the Turkish context is not simply for public good, but it is often a base for conflict. When, one talks about the identity of a settlement or a living environment, it should be understood that the residents of those cities or environment refer to the intrinsic qualities that they think the city possesses, a kind of idealization constituted around the shared values, or a bulk of objectives [7]. This kind of evaluation bears some potential to project the future around an ideal at the societal level. A construction of identity around a common will makes it societal instead individualistic. This kind of projection bears different thinking and assessments, with this respect it is intersubjective citizens can make sacrifice as long as they ascribe values to their living environment. The elements that constitute a settlement's identity are not limited solely to physical environment or natural environment. Experiences, memories, social relations transferred by generation to the new comers, as well as private memory walks and personal retreats, should be taken into consideration as identity elements. The identity elements are constituted in time. However it is not static; it has been subject to change in history and will be a subject to change in the future. "How the identity will be constructed" process or how it will be get into touch within the planning-design process, is vital, especially in the "cultural heritage" issue.

In this part of the study, in-depth interviews were done with the Islanders and Statesmen of different administrative institutions. There is somehow integral integrity by looking at the definitions of the Islanders. Almost all the participants in this study stressed the importance of the viticulture for the Island. The question "what are the main components which give the Island its intrinsic quality" has been answered by the majority as the "vineyards". Island's wines, its high quality grapes, are the complimentary attributes which creates a coherent unity for the Islanders. The sea, the shoreline and how the wind manipulates the rhythm of the daily life are the qualities mentioned so oftenly. The streetscapes, its vernacular architecture, mosques, church and mostly demolished windmills give the character to the intrinsic siluettes of the Island on approach from the mainland.

Another point that draws attention is that people from different ethnic groups and religions living together in peace. The identity elements that set aside Bozcaada from other settlements are rooted on the social life and culture of Turkish-Greek societies and togetherness. The culture of two different societies living together must have played a role as some respondents point out that there are single women from all ages who live in the Island feel very comfortable and safe, and foreigners who settled here feel at home and not as foreigners. The responses to the question of "How would you like to see the Island in the future?" are grouped in two categories: (1) It is emphasized that the Island with well-preserved natural and cultural features, a "unique" island in the world, or an island as a "model". (2) Responses of mostly the Islanders who were born there "As it was in my childhood", "Together with the people whom we used to live with" and a wish to preserve the society of two different cultureswhich are unique to this Island. 


\section{Social cohesion}

In the data set, we have information of the 40 households and 120 people. The questionnaires were distributed on March 21-29, 2011 and the sampling is five (5) per cent of the census population of Bozcaada. To cover all the settlement area, all the questionnaires were taken from almost every street and houses were chosen randomly. The two areas are of importance for the social cohesion: (1) welfare indicators (education, employment, housing), (2) Ethnicity, immigration, and belonging. The data set contains the information of the 120 persons. The average size of the household is 3 (three).

Education as the basic component of the cultural capital and high level of education can be taken as the fundamental in the integration of the social and economic sphere. In this vein, the level of education is quite high in Bozcaada that 40 per cent of the population have high school and university degree. 53 per cent of the population work actively and wage earner is quite high whereas working for the family is the highest, which has to be interpreted with the type of the production (Table 1). Income distribution has shown that lowest income quintile is higher, a 28.6 per cent (Table 2). With the lowest and second lowest income quintiles, a 39 per cent of population have lower income, however, midincome, fourt and top income quintiles in total have reached a 61 per cent. The top income group is 4.4 times more than lowest income group. The income distribution has shown slightly an equal distribution among the quintiles and more than the absolute average households' income is high in Bozcaada. This is due to the mix-economy and availability of job in the Island. The data obtained from the Governership (kaymakamlık) of Bozcaada shows that there is fairly low level of poverty in Bozcaada as compare the rest of the nation. The demand for obtaining health coverage under the state's provision for the poor people (green card) is very low in the Island. For the winter time, the number of demand for charcoal is hardly for 60 people. The place of origin reveals that more than half of the population was born in Bozcaada (54.6 per cent) whereas some of the population was born in the town (Bayramiç) in vicinity of the Island (28.6 per cent) (Table 2). The birth place of the population from the metropolitan urban center and Istanbul is quite high (4.2 and 5.9 per cent) and indicates the level of urbanization in the Island.

\begin{tabular}{|c|c|c|c|c|c|c|c|c|c|c|c|}
\hline \multicolumn{12}{|c|}{ Table 1: } \\
\hline & Count & & & & Count & & & & Count & & \\
\hline $\begin{array}{l}\text { No school } \\
\text { completed }\end{array}$ & 12 & $\%$ & 10.4 & Wage earner & 18 & $\%$ & 28.6 & Child rearing & 7 & $\%$ & 20.6 \\
\hline Primary Sch. & 43 & $\%$ & 37.4 & Causal earner & 3 & $\%$ & \begin{tabular}{|l|l|}
4.8 \\
\end{tabular} & Retired & 6 & $\%$ & 17.6 \\
\hline $\begin{array}{l}\text { Secondary } \\
\text { schooling }\end{array}$ & 10 & $\%$ & 8.7 & $\begin{array}{c}\text { Self } \\
\text { employed }\end{array}$ & 2 & $\%$ & 3.2 & Housewife & 6 & $\%$ & 17.6 \\
\hline High school & 29 & $\%$ & 25.2 & *U.F.W & 39 & $\%$ & 61.9 & Seeking job & 1 & $\%$ & 2.9 \\
\hline University & 19 & $\%$ & 16.5 & Apprentice & 1 & $\%$ & 1.6 & $\begin{array}{c}\begin{array}{c}\text { Not wanting } \\
\text { to work }\end{array} \\
\end{array}$ & 3 & $\%$ & 8.8 \\
\hline High degree & 2 & $\%$ & 1.7 & & & & & Elder & 11 & $\%$ & 32.4 \\
\hline Total & 115 & & 0 & Total & 63 & $\%$ & 100 & Total & 34 & & 100 \\
\hline
\end{tabular}




\begin{tabular}{|c|c|c|c|c|c|c|c|c|}
\hline \multicolumn{9}{|c|}{ Table 2: } \\
\hline \multicolumn{3}{|c|}{ Income Quintiles (20 \%) } & \multicolumn{3}{|c|}{ Places of Birth } & \multicolumn{3}{|c|}{ Ownership status of the House } \\
\hline & Count & Percent & & Count & Percent & & Count & Percent \\
\hline Lowest & 8 & 28.6 & Bozcaada & 65 & 54.6 & Tenant & 11 & 27.5 \\
\hline 2. lowest & 3 & 10.7 & Istanbul & 7 & 5.9 & Tenure & 26 & 65 \\
\hline Mid & 6 & 21.4 & Metropolitan city** & 5 & 4.2 & \multirow{3}{*}{$\begin{array}{l}\text { Not paid } \\
\text { (belongs to } \\
\text { the family) }\end{array}$} & \multirow[t]{3}{*}{3} & \multirow[t]{3}{*}{7.5} \\
\hline Fourth & 6 & 21.4 & City & 7 & 5.9 & & & \\
\hline Top & 5 & 17.9 & T.A.M.R* & 34 & 28.6 & & & \\
\hline & & & Abroad & 1 & 0.8 & & & \\
\hline Total & 28 & 100 & Total & 119 & 100 & Total & 40 & 100 \\
\hline
\end{tabular}

For the information about the ethnicity, the mother tongue is taken and 87.5 per cent of the population is Turkish and 7.5 per cent Greek, and 5 per cent another ethnicity. The absolute majority of the population feel him/herself as part of Bozcaada and there is almost no sign of exclusion or relion xenophopia against other relions or ethinicty in the Island in general (Table 3). The information provided by the respondents reveals that there is slightly coherent and peaceful community life in the Island. However, underneath the questionnairies, though not heavily, there is continued existence of frictions between different groups. The Islanders are the groups of many different background and places. The first is the native Islanders, who have been living in Bozcaada for generations, the second, the Istanbulites who are mainly the owner of the hotels as well as an intellectual group who discovered the island when the transportation was underdeveloped and the travel to the Island was hard, and lived on the Island long enough to consider themselves as the Islanders. The last group are the workers who come mainly from the mainland in the vicinity of town of Bayramiç, who work hard and do almost all kinds of labour and the most despised among the entire group.

\begin{tabular}{|c|c|c||c|c|c||c|c|c|}
\hline \multicolumn{7}{|c|}{ Table 3: Inclusion, exclusion and belonging. } \\
\hline I & \multicolumn{2}{|c|}{ II } & & & & \\
\hline & & $\%$ & & & $\%$ & & & $\%$ \\
\hline Agreed partially & 2 & 5.0 & Agreed partially & 2 & 5.0 & Yes & 27 & $\mathbf{8 1 . 8}$ \\
\hline Strongly disagree & 38 & $\mathbf{9 5 . 0}$ & Disagreed & 1 & 2.5 & No & 6 & 18.2 \\
\hline & & & Strongly disagreed & 37 & $\mathbf{9 2 . 5}$ & & & \\
\hline Total & 40 & 100 & Total & 40 & 100 & Total & 33 & 100 \\
\hline
\end{tabular}

I I cannot accept being neighborly with someone out of my religion, II I cannot make shopping from someone out of my religion. III I feel myself belonging to Bozcaada

\section{Legal and administrative structure}

Bozcaada's municipality does not have sufficient number of technical staff (an architect and a map tecnician) and expertise to handle all those excessive public work and heritage issues. The main complaints in part of the municipality can be summarised as; (1) the bureaucracy and all kinds of paperworks are extremely painfull, exhausting and time consuming; (2) The plan's decisions, or local demand sometimes contradict with the Çanakkale Regional Conservation Committee's decisions or remarks; (3) The committee holds a meeting once a year and it is not sufficient to solve the deep problems of the Island. 
Since the conservation is part of the public domain, tax exemption is provided for the property owners whose property has been declared of historical value and the contribution margin for the individual users and for the municipalities who administer conservation areas has been increased and diversified New ways of exchanging the privately owned historical property with government owned nonhistorical property have been introduced. However, this study has shown limited benefits of the new regulations and organizations. In the interviews, the municipality officials have not shown substantial individual effort to tap into the Ministry of Tourism and Culture's "Contribution to Conservation Fund". Another handicap is the prolonged delay for the payment of the funds, since the Ministry withholds the payments until the conservation project is established or after the project is completed. This process, with the added layer of painful bureaucracy, usually discourages lower-income or mid-low-income groups enabling only the groups with sustainable financial reserve to follow through.

Public administration is aware of foreign funds and the District Governor together with Municipality has exploited the European Union Fund for constructing a kindergarten to support preschool education. For the international cooperation the municipality has created a friendship link with two European cities, Valu Lui Traian in Romania and Gols in Austrias.

Despite all the negative points, it would be unfair to ignore that the institutional structuration of the legal and administrative capacity has reached some maturity, such as the Regional Conservation Committee which now operates country wide and KUDEP (Conservation, Implementation and Supervision Bureu) which operates under the direction of town municipalitiesgovernorship and provides support to the local conservation departments and targets to increase the productivity of the conservation efforts.

The study area of regional conservation committee encompasses world famous antique towns (Troia), and historical areas that witnessed the country's painful war towards the independence leading to the founding of the Turkish Republic (Çanakkale-Gallipoli War). The committee's personel and equipments are limited and not adequate handling this vast area's needs. In the committee's jurisdiction, there are 425 different sites in total and they have just three archaeologists, two urban planners, one architect and one map engineer. The work is hard and bureaucracy slows down the process enormously. The technical personnel within the town municipality and within the conservation establishments need to be educated and their numbers should be increased to meet the work load.

\section{Economic sustainability: viticulture and wine production}

The Island appears to have enjoyed its most prosperous times from the late Archaic to the end of the Hellenistic period. It was during this prosperious period that Tenedos mints its coin depicting bunch of grapes as well as wine-related artifacts such as kantharoi and amphorae [1,8]. Since the Archaic times, the viticulture and winemaking has been the Island's main cultural trait more than being the economic activity. The vineyards occupy one third of the Island 
(1185 ha) and $80 \%$ of the agricultural land (1478 ha). Out of total 5 million vine stock, 1600 tons of grapes for table consumption and 3900 tons of grapes for wine making are cultivated. There are wine grapes unique to Bozcaada like Karasakız (Kuntra), Altınbaş (Vasilaki) and Karalahna. During the latest years, there has been a move towards growing wine grapes to make French style wines, mainly Cabernet Sauvignon, Shordone, Merlot and Gamei [5].

In the Island, until the $1925 \mathrm{~s}$, the wine production was in the hands of the Greek population. After the Island became part of the Turkish Republic, the Greeks who stayed, taught the Turks wine making [9]. After the 1956, better use of machinery made it possible for more wine production and the Island's wine economy started growing. The same year, The Bozcaada Wine Making Inc. was established. Between the years of 1960-1980, there were small and big 13 wine production plants. In 1980s, the wine production stalled and many production plants went out of business. The main reason for the decline in viticulture was the high ratio of taxes which had caused many businesses to go bankrupt [9]. After 2001, the taxes have been brought down to 48 per cent. Also, in 1998, the State offered support to the Island's biggest three producers and modernized the equipment and machinery which resulted in better quality wine production. With the introduction of new grape varieties, the Island's wine production seems to have improved in recent years. The Island's producers opened up their own wine bars in 1999. Currently, there are five wine producers and two more will come in the near future. The Agricultural Development Cooperative established in 1974, has 397 members directly working with the wine industry.

However, even though there are some improvements, wine producers still have a lot of hardship and they complained about the lessening State support and losing the vineyards to development. Since the profit margin is low, some of the producers sold their lands to be used as vacation home sites. The information that I received from the Bozcaada Province Department of Agriculture supports the decline in vineyards (Table 4). The building permits for small capacity housing in vineyards approved by the Regional Conservation Committe posses a big danger for the Island's wine production. Most of the owners of these houses do not take care of the vines or simply they convert the gardens for other use. These so-called authentic houses are used only for few months during summer and most are fenced in with concerete walls which do not fit the Island's landscaping. Other factors that contribute to the decline seem to be the lack of adequate State subsidy, increasing cost of fuel, fertilizers and especially the recently increased Special Consumption Tax. Against all odds, the Islanders have been fighting to keep the viticulture alive as part of the Island's lifestyle

\begin{tabular}{|c|c|c|c|c|}
\hline \multicolumn{2}{|c}{ Table 4: } & \multicolumn{2}{c|}{ Statistics of the agricultural sector. } \\
\hline Years & $\begin{array}{c}\text { No. of farmers } \\
\text { (viticulture) }\end{array}$ & $\begin{array}{c}\text { No. of } \\
\text { Fishermen }\end{array}$ & $\begin{array}{c}\text { Cultivation Areas } \\
\text { (ha.) }\end{array}$ & $\begin{array}{c}\text { Annual product } \\
\text { (tons) }\end{array}$ \\
\hline $\mathbf{1 9 8 0}$ & 210 & 35 & 1800 & 4500 \\
\hline $\mathbf{1 9 9 0}$ & 367 & 52 & 1100 & 2000 \\
\hline $\mathbf{2 0 0 0}$ & 367 & 40 & 1100 & 3400 \\
\hline $\mathbf{2 0 1 0}$ & 397 & 29 & 1200 & 5000 \\
\hline
\end{tabular}

Source: Bozcaada Province Department of Agriculture (Bozcaada Kaymakamlığı). 
and culture. The increasing interest in wine culture across the country is an encouraging sign. Many of the Island's wine producers have been actively searching for international markets since the State taxes are still very high.

\section{Tourism}

The establishment of a regular ferry boat service from the mainland in 1996, has led to an increase in Island's tourism and to accomodate the increased number of visitors, new motels, guest houses and restaurants opened up. Today, the tourism plays an active role in Island's economy. The natural beauty of its bays, and coastal line, clean beaches and the lifestyle attract many tourists to the Island. However, among all, one of the main factors that increased the touristic activities is the Island's vineyards and wines [10]. According to the data from 'Bozcaada Tourism Office' (BOZTID), the Island has the capacity of 2500 beds and 118 registered contractors' currently function in the tourism sector. There are also guest houses run by families which can provide up to 1000 bed capacity. There has been also an increase in the numbers of foreign visitors. This may be due to the fact that the Conde Nast travel magazine's Reader Choice Awards honored Bozcaada as the second most beautiful island in the world [11]. The Island's climate and the temperature of the sea water allow a shorter summer tourism season compared to the other touristic areas of in the country. The best months to visit for enjoying the sea and sun are June, July and August. The Island's population go up in parallel to the touristic activities [12]. This seasonal increase brings its challenges. There is limited parking in the Island but the increasing number of cars coming in, cause long traffic jams along with the noise and dust. The 4-5 hours of waiting at the ferry station has been somewhat reduced due to new reservation system. The Island's underground resources are very limited and the water capacity is naturally low [12]. Most of the water to the Island is provided from Çanakkale via an undersea pipeline.

The tourism officials stated that currently most of the touristic activities in the Island are handled without a long term plan, rather by concentrating on shortterm profit. The natural attraction that lure the visitors in, seem to be in dire danger of being spoiled. The increasing number of hotels and motels seem to be damaging the authentic nature of the Island but attracting more visitors. The officials also stated the fact that they have been having hard time finding qualified employees who are trained for tourism sector [13]. Since most of the Island is under protection plan, there are no permits for new development and this brings problem of finding rentals for the workers. About $75 \%$ of the touristic facilities are run by the Islanders and the guest houses are operated wholly by the families who live in the Island. Our conversations with the tourism officials also revealed different views for the future of Island's tourism. We discovered that there is a trend to target the upscale visitors with money. There seems to be less support for short-staying tourists and tour busses that bring in the daily visitors [13]. However, some of the Island's big hotel operators seem to equate the high quality with high priced and they seem to be in an effort to frame Bozcaada within their liking and standards. Instead of advertising for the Island's cultural 
heritage and natural quality, they seem to take the easy route of advertising the Island as the new rising star. There has been on-going debate about the danger of this type advertisement and the fear that Bozcaada may one day become one of the many touristic places who have lost their popularity. The debates reveal that so far there has not been a consensus on how to attact the issue.

\section{Fishing}

Bozcaada lies on one of the major fish migration route; therefore, fishing is a vital part of the Island's economy. During the migration season, many boats, small and big, arrive at the Island for fishing. The Island is also rich with year round seafood. The local fishing is mainly done in small scale. Currently 48 fishing boats and 120 professional fishermen are registered with the port authority. In the interview with the district governor (Kaymakam), it was told that the fishing industry has been lagging behind the viticulture and the tourism and there has been a decline in the numbers of fishermen. The declining fish population during the recent years seems to have increased the stress on the fishing sector. One good thing is that increasing tourism activity in the Island seems to be creating a demand for the locally caught seafood, especially for the Island's famous calamari and sea urchin.

\section{Conclusion}

A new planning rhetoric, an integrated conservation approach, where the identity of the urban areas is taken into consideration and where the actors that shape the urban space and affected by being shaped, are included in the decision making process is needed. A conservation planning for the future of Bozcaada Island must be developed by the participatory practices drawn in line with the decisions made locally, and it must be continuously re-arranged around the mechanism to manage the process, rather than being a control instrument of the central administration. This study reveals that, in Bozcaada, different groups, which are of different interests and expectations, fight for the material resources and societal meaning. This struggle has to be comprehended as understanding of each other, making compromises, persuasion, withdrawal, as part of the relentless process for producing creative new ideas around a common ideal, leading to new solutions in the protection of cultural heritage, and making it available for the future generation. The issues must be put forward by trying to understand the dynamics that create the conflict and tension after the identification of targets leading up to grounding the "long-term benefit" and the vision shared by the majority. The short-term arrangements will undoubtedly be decided by the economic concerns. If the main preoccupation is to create a 'benefit' for all that goes beyond the instant economic return, a kind of new mechanism that 'thinks for itself' may be an option. This new mechanism has to be constituted in a horizontal fashion in which all the bodies, organizations, agencies with different responsibilities and functions come together. 
In the limited scope of this study I detected a desire in the Islanders to take the responsibility for their own affairs through increased local involvement of the community voluntarily. The newly constituted 'street talks', the affairs to publish a local 'newspaper' and constant discussions about their local problems, and the future of the Island both in terms of tourism, viticulture and wine production, the existence of high awareness and public interest by the officals and civil society organisations are evidences. They are aware of the interdependence of the each sector to another, and that the problem in one sector is deeply affected the other. The tourism sector is aware of the fact that the overuse of the resources and the deterioriation of the landscape will negatively affect their standing in the long run. The end of viticulture will cut off the essence of the place. For the viniculture and wine production, the Islanders easily understand that the existence of tourism creates a new opportunity, a mix economy for the Island. Tourism is very attractive for the young generation who generally are not willing to stay in the Island long. For those, who are occupied in the agricultural sector that the existence of tourism can create a kind of demand and a consciousness about their products. The promotion of the Island's outstanding history and cultural heritage will open new opportunities; create a kind of global partnership and appreciation even at the world level.

\section{References}

[1] Takaoğlu, T. \& Bamyacı, A. O., Continuity and Change in Rural Land Use on Tenedos/Bozcaada. Ethnoarchaeological Investigations in Rural Anatolia, ed. T. Takaoğlu, Istanbul: Ege Yayınevi, pp. 115-137, 2005.

[2] Bamyac1, A. O., Antik Dönem Denizciliğinde Tenedos/Bozcaada: Kıyısal Kullanım ve Ticaret (Tenedos/ Bozcaada, Maritime in the Antiquity: Coastal use and commerce), unpublished Msc thesis, Onsekiz Mart Üniversitesi Sosyal Bilimler Enstitüsü Arkeoloji Anabilim Dalı, Çanakkale, pp. $171,2006$.

[3] Orhonlu, C., Bozcaada'da Türk Eserleri ve Kitabeleri (Turkish Achievement and Inscription in Bozcaada), Türk Kültürü, 86, pp.139-149, 1969.

[4] Iller Bankası İmar Planlama Daire Başkanlığı (Bank of Provinces, Urban Planning Department, Bozcaada- Çanakkale, a Planning Report of the Conservation Plan of Bozcaada), 1992

[5] TC. Bozcaada Kaymakamlığı (Turkish Republic of Governership of Bozcaada) Web Site, Bozcaada-Çanakkale, www.bozcaada.gov.tr

[6] Mardan, E. Taşınmaz Kültür ve Tabiat Varlıklarını Koruma Mevzuatının Gelişimi ve Yargısal Denetim (Evolution of the Legal Aspects of the Immobile Cultural and Natural Properties and Juristic Control), Mekân Planlama ve Yargı Denetimi, eds: M. Ersoy \& H.Ç.Keskinok, Yargı Yayınevi, Ankara, pp. 156-199, 2000.

[7] Tekeli, İ., Bir Kentin Kimliği Üzerine Düşünceler (Opions on the Identity of a City), Kent Planlaması Konuşmaları, T.M.M.O.B publishing, Ankara, pp. 79-88, 1991. 
[8] Takaoğlu, T. \& Bamyacı, A. O., Antik Çağda Bozcaada (Tenedos) (Tenedos- Bozcaada in the Antiquity), Çanakkale İli Değerleri Sempozyumu (Symposium on the Assets of Çanakkale Provinces), Çanakkale Onsekiz Mart Üniversitesi, pp. 71-82, 2008.

[9] Durmuş, H., Bozcaada'nın Sosyoekonomik Yapısı ve Kültürü, unpublished Msc Thesis, Osmangazi Üniversitesi, Sosyal Bilimler Enstitüsü, pp. 202, 2006.

[10] Ayhan Kaptan, Ç., Özgün Peyzaj Karakteristiklerine Sahip Mekanlara Yönelik Bir Peyzaj Planlama Yönteminin Ortaya Konulması Bozcaada Örneği (Developing A Landscape Planning Approach For The Areas Having Unique Landscape Characteristic: The Case of Bozcaada), unpublished Phd. Thesis, Ege Üniversitesi Fen Bilimleri Enstitüsü, pp. 159, 2007

[11] Condé Nast Traveler: 2010 Readers' Choice Awards, http:// www.concierge.com/tools/travelawards/readerschoice/islands

[12] Kaptan Ayhan, Ç., Bozcaada'da Turizm Hareketlerinin Gelişimine Yerel Halkın Yaklaşımı Üzerine Bir Araştırma (The Approach of the Local Residents Towards the Developent of the Tourism Activities in Bozcaada), An Investigation Çanakkale İli Değerleri Sempozyumu (Symposium on the Assets of Çanakkale Provinces), Çanakkale Onsekiz Mart Üniversitesi, pp.17-23, 2008.

[13] Adaposta, Local Newspaper, Nisan-Ekim 2009, http://www.adaposta.com/ Index.php/

[14] Özgönül, N. Alaçatı'da Yaşam (A life in Alaçatı), Ege Mimarlık, pp. 18-25, Ocak (January) 2010. 